\title{
Analisis dan Perancangan E-Learning Adaptif di Sekolah Menengah Kejuruan
}

\author{
Winna Dharmayanti*1, Ratih Widya Nurcahyo ${ }^{2}$ \\ ${ }^{1,2}$ Program Studi Pendidikan Teknologi Informasi dan Komputer, IKIP PGRI Pontianak \\ dharmayantiwinna@gmail.com*1, ratihwidya01@gmail.com ${ }^{2}$
}

(Received: 4 September 2020 / Accepted: 1 Maret 2021 / Published Online: 20 Juni 2021)

\begin{abstract}
Abstrak
Sekolah belum memanfaatkan penggunaan teknologi untuk melakukan pembelajaran 4.0 yang berbasis online, sedangkan sekolah memiliki laboratorium komputer dan jaringan internet. Guru dan siswa membutuhkan media e-learning yang dapat digunakan dalam pembelajaran di luar kelas. Adapun tujuan dari penelitian ini untuk menganalisis dan merancang media e-learning adaptif yang sesuai dengan kebutuhan guru dan siswa di SMK Mandiri. Adapun tujuan dari penelitian ini untuk mengkaji dan merancang media pembelajaran e-learning adaptif yang sesuai dengan yang dibutuhkan oleh guru dan siswa di SMK Mandiri. Metode yang digunakan dalam penelitian ini ialah metode R\&D menggunakan model ADDIE dengan hanya tahapan Analisis dan Desain,. Subjek penelitian pengembangan ini adalah expert media dan expert sistem e-learning. Pengumpulan data yang digunakan adalah teknik komunikasi langsung dan tidak langsung, yaitu dilakukan secara virtual untuk mengetahui kebutuhan guru dan siswa serta menggunakan angket untuk mengetahui tingkat kelayakan produk. Hasil penelitian ini menunjukan bahwa adanya kebutuhan media e-learning adaptif dan adanya perancangan desain media e-lerning di SMK Mandiri. Kesimpulan hasil penelitian ini ialah menganalisis media e-learning adaptif yang dibutuhkan adalah media e-learning yang bisa menampilkan 3 gaya gaya belajar siswa yakni, visual, auditori dan kinestetik, kemudian mendesain perancangan media e-learning adaptif. membuat flowcart untuk menggambarkan perancangan media e-learning.
\end{abstract}

Kata Kunci: ADDIE, Adaptif, E-learning

\section{Abstract}

Schools have not taken advantage in using technology to carry out online-based learning 4.0, though schools have computer laboratories and Internet networks. Teachers and students need e-learning media (ELM) that can be used in learning outside the classroom. The aim of this study is to analyze and design adaptive of ELM according to the needs of teachers and students at SMK Mandiri. The purpose of this study is to study to examine and to design of ELM in accordance with what is needed by teachers and students at SMK Mandiri. The method used in this research is $R$ \& D method apply ADDIE model by analyzing and designing stages only. The subjects of this development research were media expert and e-learning system expert. Data collection used is direct and indirect communication techniques, which is done virtually to determine the needs of teachers and students and questionnaire to determine the level of product feasibility. The results of this study indicate that there is a need for ELM-adaptive and designs at SMK Mandiri. The conclusion from this research is to analyze the ELM-adaptive, which can display three styles of student learning styles, namely, visual, auditory and kinesthetic, then designing and create a flow cart to describe ELM.

Keywords: ADDIE, Adaptive, E-learning,

\section{PENDAHULUAN}

Saat ini dimana pembelajaran dapat dilakukan secara online terbuka bagi siapa saja, kapan saja, dimana saja tanpa dibatasi oleh ruang dan waktu melalui e-learning. E-learning adaptif merupakan salah satu sistem e-learning yang digunakan pada proses pembelajaran, dimana sistem tersebut didesign dengan menyesuaikan gaya belajar yang memakainya, dalam 
hal ini adalah siswa. Surjono (2015: 21) mendefiniskan e-learning adaptif sebagai suatu sistem $e$-learning yang secara keseluruhan menyesuaikan rangkaian penyampaian informasi dan susunan hubungan, yang disampaikan dengan menyesuaikan karakteristik gaya belajarnya. Sedangkan gaya belajar merupakan cara siswa dalam mengolah informasi yang yang telah didapatkan sesuai dengan karakteristik siswa masing-masing, setiap siswa mempunyai gaya belajar yang dominan dan minoritas, biasanya gaya belajar yang dominan lebih disukai siswa, karena siswa dapat memanfaatkan waktu secara efisien dan secara produktif (Brahmantio \& Anistyasari, 2020).

Berdasarkan hasil observasi di SMK Mandiri di Pontianak teridentifikasi beberapa permasalahan diantaranya adalah proses pembelajaran masih bersifat konvensional tatap muka di dalam kelas, khususnya masih belum memanfaatkan penggunaan teknologi untuk melakukan pembelajaran 4.0 yang berbasis online, sementara fasilitas pendukung yang dimiliki oleh sekolah telah memadai. Adapun fasilitas yang dimiliki diantaranya sekolah sudah memiliki laboratorium komputer, internet dan merupakan salah satu sekolah yang sudah mengimplementasikan ujian nasional berbasis komputer. Pada Dasarnya Perkembangan Teknologi Informasi dan Komunikasi perlu dikembangkan sistem e-learning yang mampu untuk mengakomodasi permasalah perbedaan karakteristik siswa, yang dapat mengetahui preferensi siswa dan berupaya untuk menyampaikan konten serta menggunakan metode yang sesuai dengan karakeristik siswa (Putra, Dantes, \& Ernanda, 2019).

Lebih lanjut, metode pembelajaran yang diterapkan masih bersifat konvensional, dalam artian masih menggunakan teacher-centered dan tidak memperhatikan gaya belajar yang dimiliki oleh siswa, dimana setiap siswa memiliki gaya belajar yang berbeda-beda. Berdasarkan hasil observasi tersebut maka dilakukanya studi pendahuluan yang diperoleh informasi bahwa keinginan guru dan siswa yakni dibutuhkannya media yang dapat menunjang pembelajaran di luar kelas misalnya menggunakan e-learning, siswa juga menharapkan sistem pemebalajaran yang menyesuaikan dengan gaya belajarnya masingmasing. Gaya belajar merupakan kebiasaan seseorang merasa paling efisien dan efektif dalam memproses, menerima dan menyimpan sesuatu yang dipelajari. Gaya belajar dalam konteks pembelajaran, dapat dipahami sebagai suatu pendekatan dalam rangka mengefektifkan pembelajaran dalam rangka mencapai hasil belajar yang lebih baik.

Terdapat penelitian terkait perancangan media e-lerning berdasarkan gaya belajar, yang dirancang untuk membuat siswa lebih aktif dalam melakukan proses pembelajaran (Dharmayanti, Verawardina, \& Nurcahyo, 2018). Pada penelitian lain menggunakan $e$ learning berdasarkan gaya belajar diterapkan untuk mengembangan e-learning adaptif dilandasi oleh beberapa teori belajar. Pengembangan e-learning dengan melandasi pada teori belajar supaya pesan yang didesaian dapat tersampai kepada siswa (Ziaurrahman \& Surjono, 2017). Berdasarkan hasil hipotesis adanya perbedaan antara pembelajaran e-learning dengan pembelajaran konvensional dari hasil belajar dari kedua sistem tersebut (Thoyib, Subandowo, \& Wiyarno, 2021).

Pada umumnya sistem e-learning yang sudah ada sekarang ini hanya mampu menyajikan bahan ajar yang sama untuk semua pengguna media e-leraning tanpa mempertimbangkan karakteristik mereka. E-learning ini sebenarnya cocok untuk siswa yang homogen. siswa dengan gaya belajar dan pengetahuan awal yang berbeda-beda tidak bisa belajar secara optimal melalui e-learning tersebut karena materi yang diberikan tidak sesuai dengankebutuhannya. Dengan demikian mereka memerlukan $e$-learning yang bersifat adaptif yaitu suatu e-learning yang bisa menyesuaikan dengan latar belakang pengguna (Surjono \& Nurkhamid, 2008).

Berdasarkan kebutuhan tersebut maka menawarkan sebuah pengembangan media $e$ learning adaptif yaitu media pembelajaran yang dapat diakses dimana dan kapan saja yang ditampilkan sesuai dengan karakteristik keragaman gaya belajar pengguna yakni gaya belajar 
Visual (Penglihatan), Auditori (Pendengaran) dan Kinestetik (Pergerakan). Siswa dapat melakukan proses pembelajaran sesuai dengan karakteristik masing-masing dalam hal kebutuhan gaya belajar.

Adapun tujuan utama dari penelitian ini untuk mengkaji dan merancang media $e$ learning adaptif yang dibutuhkan oleh guru dan siswa dengan memakai bahasa pemrograman php dan mysql, sehingga dapat menghasilkan media e-learning adaptif yang menyesuaikan gaya belajar siswa seperti kinestetik, visual, dan auditori. Diharapkan mampu membantu siswa dalam memahami materi yang di pelajari sesuai dengan keberagaman gaya belajar yang ada di SMK Mandiri Pontianak.

\section{METODE}

Penelitian ini menggunakan metode Research and Development (R\&D). Metode ini merupakan suatu metode yang melakukan suatu proses pengembangan perangkat pendidikan yang dilakukan melalui serangkaian riset yang menggunakan berbagai metode dalam suatu siklus yang melewati berbagai tahapan (Ali \& Asrori, 2014). Model yang digunakan adalah ADDIE. Model ADDIE terdiri dari 5 tahapan, yakni Analisis (Analysis), Perancangan (Design), Pengembangan (Depelopment), Implementasi (Implementation) dan Evaluasi (Evaluation) (Hakky, Wirasasmita, \& Uska, 2018; Irawan \& Wirasasmita, 2019; Sabirin, Sulistiyarini, \& Zulkarnain, 2020; Siddik \& Kholisho, 2019). Batasan dari penelitian ini adalah penelitian ini hanya dilakukan sampai pada tahap Design (Branch, 2010). Subjek penelitian ini adalah ahli media dan ahli sistem e-learning, untuk menganalisis kebutuhan media e-learning yang akan dikembangkan. Teknik pengumpulan data yang digunakan adalah teknik komunikasi langsung melalui wawancara, alat pengumpulan data adalah petunjuk acuan wawancara yang di susun untuk mendapatkan infomasi kebutuhan guru dan siswa, dan teknik komunikasi tidak langsung menggunakan angket kelayakan produk media e-leraning.

\section{HASIL DAN PEMBAHASAN Hasil}

Berdasarkan hasil analisis dan design media e-learning adaptif dapat diuraikan berberapa tahapan model pengembangan produk yakni Analysis (Analisis), Design (Perancangan), Depelopment (pengembangan), Implementation (Implementasi) dan Evaluation (Evaluasi) sebagai berikut. Tahap Analysis (Analisis) menganalisis kebutuhan guru dan siswa pada SMK Mandiri Pontianak, tampilan desain, letak navigasi dan lain sebagainya, dilakukan wawancara kepada siswa urusan Multimedia 1 dan Multimedia 2 diperoleh informasi bahwa siswa menginginkan media e-lerning yang menarik dan mudah digunakan sesuai dengan gaya belajar visual yang menarik, gaya belajar auditori siswa lebih menekankan pada kejelasan suara yang di keluarkan dan penjelasan yang tidak terlalu cepat, gaya belajar kinestetik adanya tutorial yang jelas dalam mendeskripsikan materi yang disampaikan, adanya tombol navigasi untuk mempermudah siswa dalam menggunakan media. Adapun serangkaian informasi tambahan pada media e-learning adaptif yang diperlukan siswa adalah: a) Tampilan media di susun secara menarik, tampilan halaman yang simpel mudah digunakan dan responsive, b) Letak navigasi yang diinginkan merspon dengan cepat dan interaktif, c) Pada tampilan home tersedia kelas anda, mata pelajaran, materi, tugas/quis, dan forum diskusi yang dapat dipakai untuk berdiskusi dan komunikasi dengan guru.

Analisis kebutuhan guru yang berdasarkan pada hasil wawancara terhadap guru ditemukan bahwa guru SMK Mandiri Pontianak membutuhkan bantuan media e-learning adaptif sebagai alternatif guru dalam memberikan materi pada siswa, yang pada saat ini proses pembelajaran yang berubah dari pembelajaran tatap muka, menjadi pembelajaran jarak 
jauh, yang sesuai dengan mata pelajaran, guru membutuhkan media e-learning yang mudah diakses kapan saja dimana saja. Guru juga dapat mengontrolan nilai siswa, serta juga didapat serangkaian informasi yang ada di media e-learning adaptif yang diperlukan oleh guru diantaranya sebagai berikut: a) Tampilan media dirancang dengan layout yang simpel, untuk warna yang digunakan menggunakan warna yang serasi sehingga tidak membuat mata lelah dan menarik, b) Tombol navigasi untuk masuk ke media terdiri dari menu login.menggunakan email dan password c) Pada tampilan home tersedia manajeman mata pelajaran, manajeman evaluasi, manajeman materi, forum diskusi yang dapat digunakan untuk berdiskusi dan komunikasi dengan siswa. Untuk penyajian materi dalam wujud 3 gaya belajar yakni gaya belajar visual yang menggunakan media gambar dan video. gaya belajar auditori menggunakan narasi audio dan teks. Sedangkan untuk Pada gaya belajar kinestetik dirancang dengan konsep tutorial.

Analisis kebutuhan media pembelajaran e-learning adaptif yang merujuk pada hasil analisis kebutuhan penyusunan media e-learning adaptif memerlukan peralatan komputer atau perangkat lainnya, jaringan internet, memerlukan hosting dan domain untuk penyimpanan arsip media e-learning adaptif dan materi. Adapun spesifikasi untuk mengoperasikan produk ini sebagai berikut: a) Perangkat keras komputer atau smart phone memakai sistem operasi Windows, b) Jaringan internet, mouse, touch ped, dan speaker untuk audio, c) Web browser seperti Google Chrome, mozilla d) petunjuk penggunaan produk, aplikasi pemutar audio dan video, serta aplikasi adobe flash.

Tahap perancangan, tahap ini merupakan tahap desain, berdasarkan dari analisis kebutuhan yang dilakukan kepada guru dan siswa SMK Mandiri Pontianak, kemudian dibuatlah desain perancangannya oleh ahli. Maka perlu adanya klarifikasi pada produk media e-learning adaptif yang sedang dikembangkan serta perincian yang didesain, sehingga produk tersebut dapat sesuai dengan kebutuhan siswa dan guru. Perancangan dimulai dari penyusunan flowchart yang bertujuan untuk mengelola media e-learning adaptif. Berikut flowchart media e-learning adaptif.kemudian rancangan desain produk, setelah produk selesai produk divalidator oleh pakar ahli. Jika valid lakukan uji coba Produk, Jika tidak lakukan revisi produk hingga produk dinyatakan valid. Setelah melakukan uji coba produk, sebarkan angket kepada subjek penelitian, maka dari angket itu kita akan mendapat data uji praktikalitas untuk menentukan apakah produk yang kita buat praktis atau tidak, pada langkah uji coba produk itu juga menentukan apakah produk yang kita buat efektif atau tidak. Pada flowcart (gambar 1) dapat dilihat dari mulai awal menentukan analisis kebutuhan, dan mendesain produk, melakukan revisi produk jika ada yang kurang akan direvisi, jika sudah melakukan revisi dan hasil valid. Maka prodak akan diuji cobakan terlebih dahulu, kemudian siswa diberikan angket untuk melihat praktis dan efektivitasnya. Kebutuhan Media e-learning adaptif akan dibuat dengan menyesuaikan hasil analisis kebutuhan siswa dan guru berdasar pada gaya belajar. Sehingga, dari hasil analisis kebutuhan media e-learning adaptif melihat gaya belajar siswa bersifat kinestetik, auditori dan video. Menurut guru pengampuh mata pelajaran media e-learning adaptif sangat dibutuhkan dan bermanfaat bagi siswa dalam memahami materi, apalagi dengan proses pembelajaran jarak jauh yang sedang dilakukan. Sehingga siswa mempunyai kesulitan dalam memahami materi yang bervariasi. Media $e$ learning adaptif diperlukan oleh guru sebagai media dalam menjelaskan materi yang di sampaikan dengan lebih fleksibel dimana saja dan kapan saja. Diharapkan, dengan pemanfaatan media e-learning adaptif dapat memotivasi siswa dalam pembelajaran karena sesuai dengan belajar masing-masing siswa. Selain itu seluruh siswa dapat melihat media sesuai dengan gaya belajar tersebut. Sehingga siswa yang belum termotivasi dalam belajar menjadi lebih termotivasi dalam pembelajaran karena adanya media yang sesuai dengan gaya belajar. 


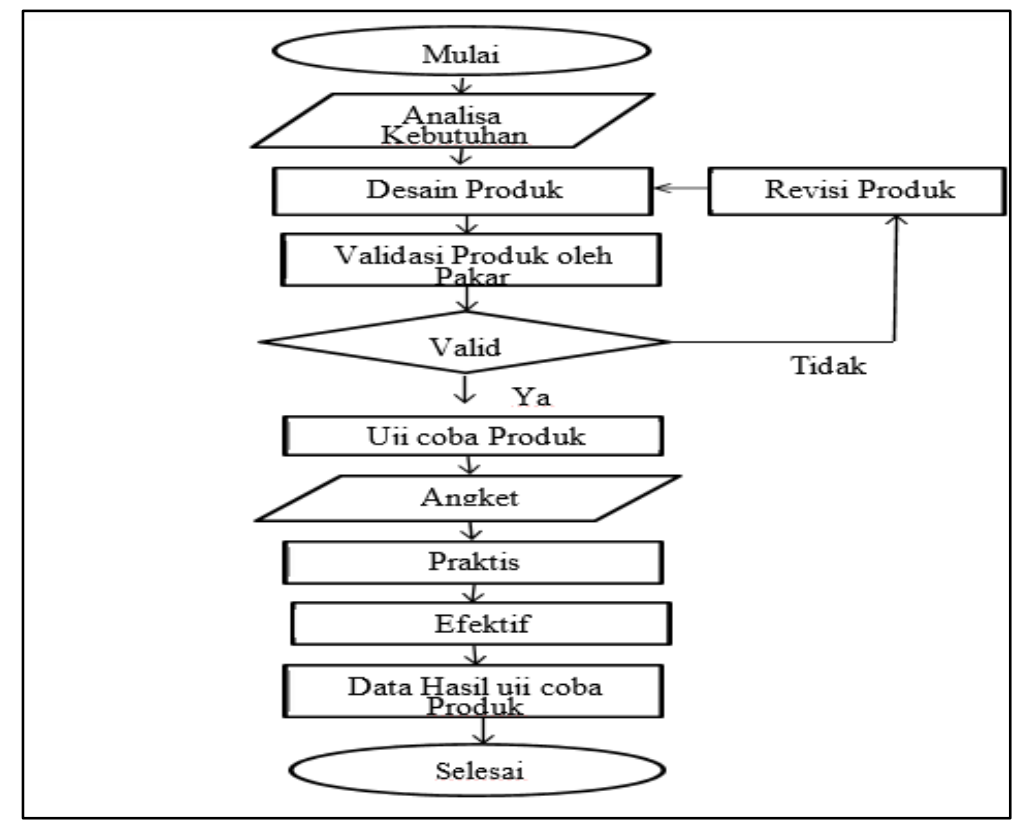

Gambar 1: Flowchart Media E-learning Adaptif.

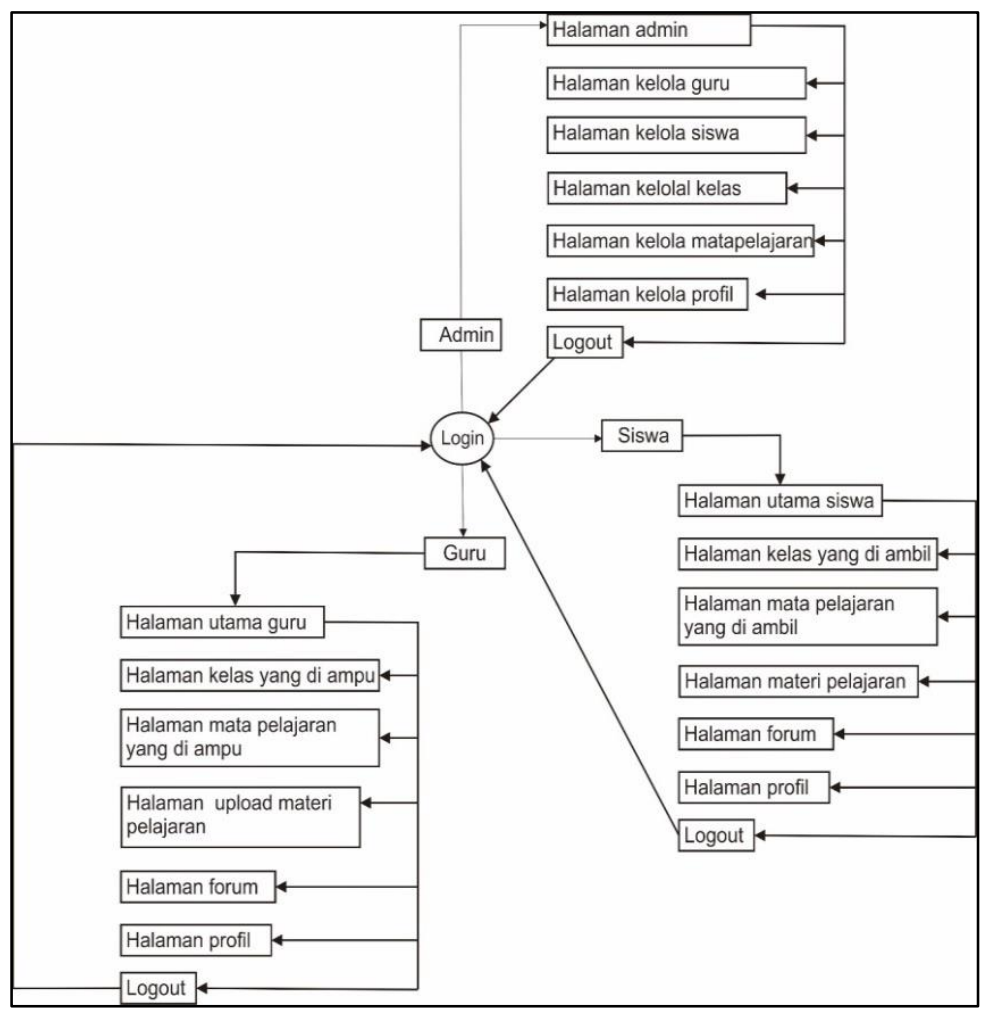

Gambar 2 : Rancangan Alur Penggunaan E-Learning

Media e-learning adaptif berdasarkan gaya belajar ini mempunyai kelebihan diantaranya adalah dapat didesign secara online sehingga dapat diakses kapan saja dan dimana saja tanpa dibatasi oleh ruang, jarak, dan waktu. Kemudian perancangan media ini disesuaikan dengan gaya belajar yang dimiliki oleh siswa, diantaranya gaya belajar kinestetik, visual dan auditori. Telah terbukti bahwa penggunaan Media e-learning adaptif dalam proses pembelejaran yang sesuai dengan kebutuhan siswa dapat membantu dalam peningkatan hasil belajar siswa dan dapat terimplementasikan secara efektif (Surjono, 2013: 12). 
Oleh karena itu, analisis dan perancangan media e-leaning adaptif ini diharapkan dapat menyajikan alternatif yang berbeda dalam pembelajaran yang ada di SMK Mandiri Pontianak, dalam mengatasi media sesuai kebutuhan, dan situasi kondisi saat ini, serta meningkatkan hasil belajar siswa. Guna menjabarkan hasil dari design media e-learning Adapatif maka dibuatlah flowchart yang bertujuan untuk memberikan gambaran berupa alur dari pengembangan media e-learning adaptif. Media e-learning adaptif didesign dengan rancangan tampilan yang sederhana, dengan memadupadankan keselarahan warna yang sesuai antara satu dengan yang lainnya. Perancangan produk adalah dijadikan sebagai input kebutuhan guru yakni menu home, manajemen mata pelajaran, manajemen evaluasi, manajeme materi, forum, dan Posting topik sedangkan kebutuhan siswa, yakni menu home kelas, mata pelajaran, materi, evaluasi, nilai, forum, Posting Topik, edit Profil, dan akun.

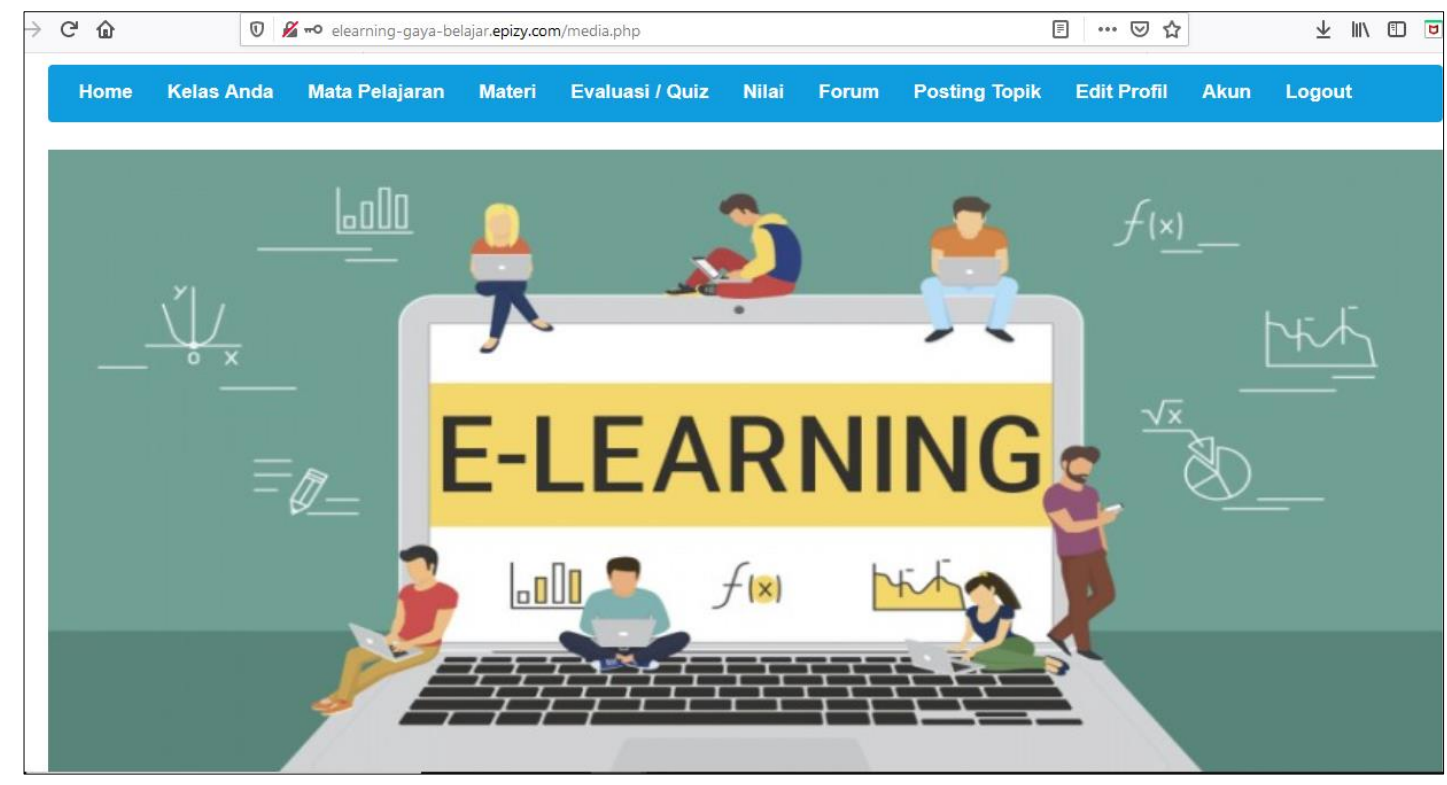

Gambar 3. Tampilan Media E-learning untuk siswa

Pada bagian validasi ahli media dilakukanya penilaian kelayakan produk media $e$ learning adaptif yang berdasar pada gaya belajar. Adapun penilaiannya mencakup aspek lingkungan pembelajaran, informasi tambahan, antar muka, navigasi, pedagogik, fitur, aspek kehandalan dengan total pertanyaan angket kelayakan media berjumlah 39 melalui penialian rating scale 1-4. Sebelumnya ditampilkan konversi skor validasi oleh ahli media dan kategorinya sesuai rumus yang ada yang dapat dilihat pada tabel 1 .

Selanjutnya pada tabel 2 adalah hasil perhitungan untuk masing-masing aspek yakni jumlah pada aspek lingkungan pembelajaran dengan rerata skor sebesar 3,70. Pada aspek informasi tambahan rerata skor sebesar 3,50. Pada aspek antar muka rerata skor sebesar 3,56, aspek navigasi rerata skor sebesar 3,33, aspek pedagogik rerata skor sebesar 3,4, aspek fitur rerata skor sebesar 3,4 dan pada aspek kehandalan rerata skor sebesar 3,62. Sedangkan perolehan keseluruhan aspek pada ahli media 1 rerata sebesar 3,52 dengan persentase $87,82 \%$, sedangkan prolehan keseluruhan aspek pada ahli media 2 rerata sebesar 3,57, dengan persentasi 89,74\%, dan untuk keseluruhan aspek pada kedua ahli media tersebut sebesar 3,55. Sedangkan untuk persentase sebesar $88,78 \%$. Berikut juga ditampilkan grafik hasil valisasi ahli media yang dapat dilihat pada gambar 5 . 


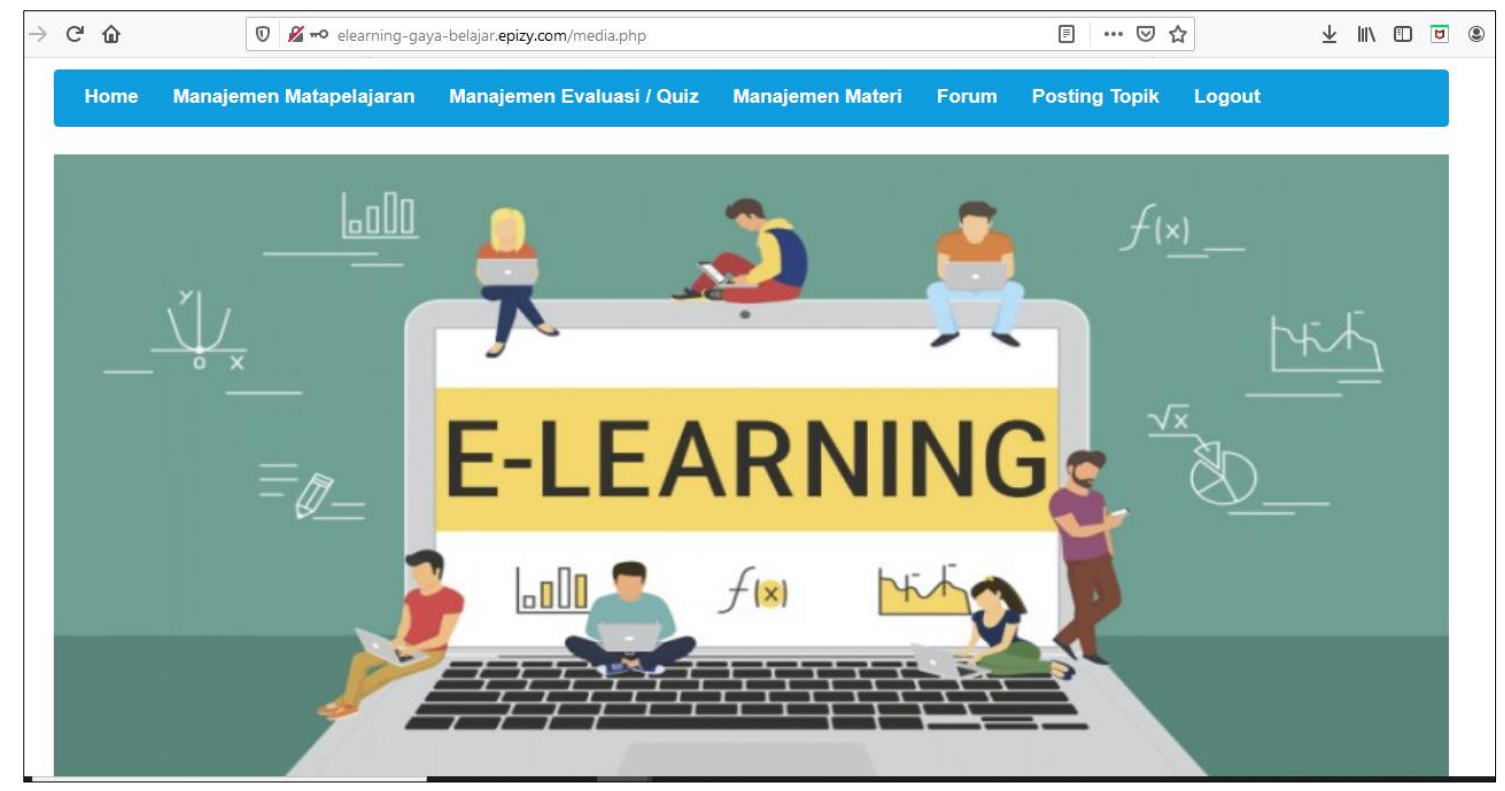

Gambar 4. Tampilan Media E-learning untuk Guru

Table 1. Konversi Skor Validasi oleh Ahli Media

\begin{tabular}{cc}
\hline Rerata Skor & Kategori \\
\hline$>\mathbf{3}, 40$ & Sangat baik \\
$>\mathbf{2}, \mathbf{8 0}-\mathbf{3}, 40$ & Baik \\
$>\mathbf{2}, 20-2,80$ & Cukupbaik \\
$>\mathbf{1 , 6 0 - 2 , 2 0}$ & Kurang \\
$\leq 1,60$ & Sangat kurang \\
\hline
\end{tabular}

Tabel 2. Hasil Validasi Ahli Media

\begin{tabular}{|c|c|c|c|c|c|}
\hline \multirow[b]{2}{*}{ Aspek } & \multicolumn{2}{|c|}{ Ahli Media 1} & \multicolumn{2}{|c|}{ Ahli Media 2} & \multirow{2}{*}{$\begin{array}{c}\text { Total Rerata } \\
\text { Skor Ahli } \\
\text { Media }\end{array}$} \\
\hline & Skor & Rerata & Skor & Rerata & \\
\hline Lingkungan Pembelajaran & 22 & 3,60 & 23 & 3,80 & 3,70 \\
\hline Informasi tambahan & 11 & 3,67 & 10 & 3,33 & 3,5 \\
\hline Antar Muka & 54 & 3,60 & 53 & 3,53 & 3,56 \\
\hline Navigasi & 9 & 3,00 & 11 & 3,67 & 3,33 \\
\hline Pedagogik & 16 & 3,2 & 18 & 3,6 & 3,4 \\
\hline Fitur & 11 & 3,2 & 10 & 3,6 & 3,4 \\
\hline Aspek kehandalan & 14 & 3,5 & 15 & 3,75 & 3,62 \\
\hline Rerata skor akhir & \multicolumn{2}{|c|}{3,52} & \multicolumn{2}{|c|}{3,57} & 3,55 \\
\hline Kategori & \multicolumn{2}{|c|}{ Sangat Baik } & \multicolumn{2}{|c|}{ Sangat Baik } & Sangat Baik \\
\hline Total Persentase & \multicolumn{2}{|c|}{$87,82 \%$} & \multicolumn{2}{|c|}{$89,74 \%$} & $88,78 \%$ \\
\hline
\end{tabular}

Hasil validasi ahli media 1 memperoleh rerata skor sebesar 3,52, dan ahli media 2 memperoleh rerata skor 3,57. Sedangkan hasil keseluruhan ahli media sebesar 3,555. Hasil keseluruhan tersebut berada pada rentang skor akhir $>3,40$ menyatakan bahwa produk tersebut sangat baik dan layak untuk digunakan, sehingga dapat dilanjutkan kepada tahapa berikutnya yakni ujicoba. 


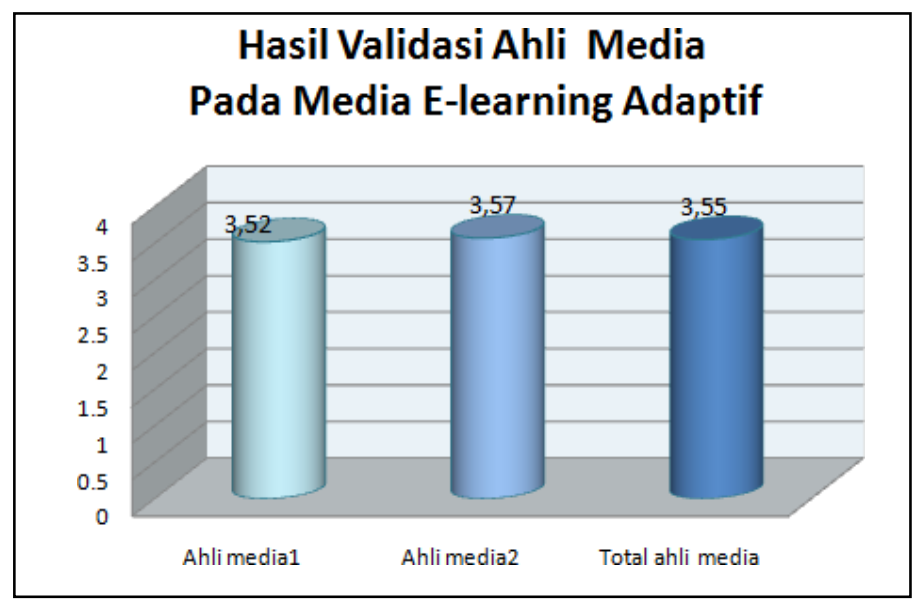

Gambar 5. Hasil Validasi Ahli Media

\section{Pembahasan}

E-learning Adaptif berdasarkan gaya belajar ini merupakan, e-learning yang sederhana yang mudah digunakan untuk guru dan siswa. Berdasarkan dari penemuan dilapangan terdapat kebutuhan media untuk guru dan siswa dalam proses pembelajaran yakni media e-learning adaptif di SMK Mandiri Pontianak, yang telah di analisis dan di lakukan peracangan sesuai dengan hasil wawancara dilapangan hasil validasi ahli media dan ahli sistem e-learning yaitu 2 orang dosen Program Studi Pendidikan Teknologi Informasi dan Komputer. Perolehan keseluruhan aspek pada ahli media 2 rerata sebesar 3,57, dengan persentasi 89,74\%, dan untuk keseluruhan aspek pada kedua ahli media tersebut sebesar 3,55. Sedangkan untuk persentase sebesar $88,78 \%$ berdasarkan hasil validasi produk oleh ahli media dan ahli sistem e-learning, diperoleh rentang skor akhir > 3,40 menyatakan bahwa produk media e-learning adaptif yang berdasar pada gaya belajar layak dan efektif untuk digunakan dalam proses pembelajaran di SMK Mandiri Pontianak. Karena dibuat sesuai dengan kebutuhan guru dan siswa. Dengan menggunakan e-learning berdasarkan gaya belajar di terapkan untuk mengembangan e-learning adaptif sesuai dengan gaya belajar dilandasi oleh beberapa teori belajar. Pengembangan e-learning dengan melandasi pada teori belajar supaya pesan yang didesaian dapat tersampai kepada siswa (Ziaurrahman \& Surjono, 2017). Diharapkan dengan digunakannya media e-learning adaptif berdasarkan gaya belajar, mampu menjadikan proses pembelajaran yang semula berpusat kepada guru menjadi terpusat kepada siswa.sesuai dengan pembelajaran abad 21. Sejalan dengan Penelitian lain yakni $e$ learning adaptive sangat layak digunakan untuk mengatasi keberagaman gaya belajar pada pendidikan vokasi (Setiawan \& Sudomo, 2019). Pengembangan e-learning adaptif dapat memfasilitasi sajian materi sesuai dengan karakteristik siswa seperti tingkat pengetahuan awal, asal daerah dan ketepatan belajar siswa (Surahman \& Surjono, 2017). Implementasi $e$ learning dalam pembelajaran akan melahirkan sumber daya manusia yang mengenal serta mampu berinteraksi dan menggunakan teknologi informasi dan komunikasi (internet) untuk mempersiapkan diri mejadi generasi yang unggul dalam pengetahuan dan teknologi (Sari, 2017).

\section{SIMPULAN}

Berdasarkan pemaparan diatas, adapun hasil dalam penelitian ini yaitu menganalisis dan merancangan media e-learning adaptif yang menyesuaikan dengan gaya belajar, dengan menggunakan model ADDIE yang terdisi dari tahapan Analysis, Design, Development, Implementation dan Evaluation. Penelitian ini hanya sampai pada tahap analisis dan desain dengan tujuan untuk mengetahui kebutuhan dan rancangan produk. Berikut adalah hasil dari 
tahap analisis untuk menganalisis kebutuhan siswa, dan guru pada media $e$-learning adaptif seperti desain, navigasi , tampilan, lain-lain, selanjutnya tahap mendesain, yakni mendesain produk media e-learning adaptif sesuai dengan kebutuhan yakni rancangan desain dan spesifikasi produk media elearning adaptif. Berdasarkan dari hasil uji hasil validasi ahli media 1 memperoleh rerata skor sebesar 3,52, dan ahli media 2 memperoleh rerata skor 3,57. Sedangkan hasil keseluruhan ahli media sebesar 3,555. Hasil keseluruhan tersebut berada pada rentang skor akhir > 3,40 menyatakan bahwa produk media e-learning adaptif yang menyesuaikan gaya belajar tersebut sangat baik dan layak untuk digunakan.

\section{REFERENSI}

Ali, M., \& Asrori, M. (2014). Metodologi dan Aplikasi Riset Pendidikan. Jakarta: Jakarta: PT. Bumi Aksara.

Brahmantio, D. I., \& Anistyasari, Y. (2020). Studi Literatur Pengaruh Gaya Belajar Terhadap E-Learning Adaptive Berbasis Web. IT-Edu: Jurnal Information Technology and Education, 5(1), 362-370.

Branch, R. M. (2010). Instructional Design: The ADDIE Approach. New York: Springer Science+Business Media, LLC.

Dharmayanti, W., Verawardina, U., \& Nurcahyo, R. W. (2018). Analisis Dan Perancangan ELearning Adaptif Berdasarkan Gaya Belajar Pada Mata Pelajaran Simulasi Digital di SMK Negeri 7 Pontianak. Wahana Didaktika: Jurnal Ilmu Kependidikan, 16(2), 162172. https://doi.org/10.31851/wahanadidaktika.v16i2.2046

Hakky, M. K., Wirasasmita, R. H., \& Uska, M. Z. (2018). Pengembangan media pembelajaran berbasis android untuk siswa kelas x pada mata pelajaran sistem operasi. EDUMATIC: Jurnal Pendidikan Informatika, 2(1), 24-33.

Irawan, U., \& Wirasasmita, R. H. (2019). Media Pembelajaran Video Tutorial Interaktif Berbasis Adobe Flash Pada Mata Kuliah Pemrograman Dasar. Edumatic: Jurnal Pendidikan Informatika, 3(2), 84-90.

Putra, I. G. J. A., Dantes, G. R., \& Ernanda, K. Y. (2019). Adaptive Learning: Mengidentifikasi Gaya Belajar Peserta Didik Dalam Rangka Optimalisasi Sistem ELearning Dengan Menggunakan Bayesian Network. Jurnal Ilmu Komputer Indonesia, 4(2), 21-30. https://doi.org/10.23887/jik.v4i2.2773

Sabirin, F., Sulistiyarini, D., \& Zulkarnain, Z. (2020). Pengembangan Sistem Informasi Seminar dan Skripsi Mahasiswa. Edumatic: Jurnal Pendidikan Informatika, 4(1), 73-82.

Sari, I. P. (2017). Implementasi Pembelajaran Berbasis E-Learning Menggunakan Claroline. Research and Development Journal of Education, 4(1), 75-87. https://doi.org/10.30998/rdje.v4i1.2070

Setiawan, T., \& Sudomo, R. I. (2019). Mengatasi Keragaman Gaya Belajar Pada Pendidikan Tinggi dan Vokasi Melalui Pengembangan E-learning Adaptive Hypermedia System Berbasis Moodle. EDUKASIA ISLAMIKA: Jurnal Pendidikan Islam, 4(1), 99-110. https://doi.org/10.28918/jei.v4i1.2261

Siddik, B., \& Kholisho, Y. N. (2019). Pengembangan Modul Pembelajaran Perakitan Komputer Berbasis Multimedia Interaktif. EDUMATIC: Jurnal Pendidikan Informatika, 3(1), 13-19.

Surahman, E., \& Surjono, H. D. (2017). Pengembangan Adaptive Mobile Learning Pada Mata Pelajaran Biologi SMA Sebagai Upaya Mendukung Proses Blended Learning. Jurnal Inovasi Teknologi Pendidikan, 4(1), 26-37. https://doi.org/10.21831/jitp.v4i1.9723

Surjono, H. D. (2013). Membangun Course E-Learning Berbasis Moodle (2nd Ed). Yogyakarta: Yogyakarta: UNY Press.

Surjono, H. D. (2015). Adaptive And Engaging E-Learning: Inovasi Pemanfaatan Teknologi 
Informasi Dalam Pendidikan Jarak Jauh (Naskah Pengukuhan Guru Besar). Yogyakarta: UNY Press.

Surjono, H. D., \& Nurkhamid. (2008). Pengembangan Model E-Learning Adaptif Terhadap Keragaman Gaya Belajar Mahasiswa Untuk Meningkatkan Efektivitas Pembelajaran. In Universitas Negeri Yogyakarta. Yogyakarta: Yogyakarta: UNY Press.

Thoyib, M., Subandowo, M., \& Wiyarno, Y. (2021). Penerapan E-Learning dengan Analisis Pengetahuan Awal Terhadap Prestasi Belajar Bahasa Inggris Siswa SMK. Edcomtech: Jurnal Kajian Teknologi Pendidikan, 6(1), 12-23.

Ziaurrahman, Z., \& Surjono, H. D. (2017). Pengembangan E-Learning Adaptif Pada Mata Pelajaran Pendidikan Agama Islam Untuk Kelas X SMA. Jurnal Inovasi Teknologi Pendidikan, 4(2), 119-129. https://doi.org/10.21831/jitp.v4i2.10458 